\title{
The Aftermath of the Mare Nostrum Policy Quandary on Migration in Italy
}

\author{
Hamza Fadil \\ Department of Sociology, School of Public Administration Hohai University, Nanjing, China
}

\section{Shen Yi}

Department of Sociology, School of Public Administration Hohai University, Nanjing, China

Received: October 9, 2019 Accepted: November 16, 2019 Published: November 18, 2019

doi:10.5296/ijgs.v3i1.15854

URL: https://doi.org/10.5296/ijgs.v3i1.15854

\begin{abstract}
Italy is the destination for migration and Libya is the main gateway for sending migrants by sea. Political instability in Libya due to the Arab Spring became fertile ground for smugglers to send thousands of irregular migrants from mainland Africa across the Mediterranean to Europe. The number of irregular migrants who come to cause problems for Italy. Italy is a country that is quite focused on resolving irregular migrant problems, but regulations regarding migrants are still said to be unsuccessful given the growing number of migrants. Migrants who arrive are often referred to as "Marocchini" or Moroccans. This research uses the concept of norms in constructivism. Norms have standards of behavior that contain prohibitions and recommendations of action. After the cessation of Operation Mare Nostrum, Italy continued to show consistency in complying with the laws of the sea and human rights, by continuing to carry out surveillance and rescue at sea. This was reinforced by the statement of the Italian Prime Minister, Matteo Renzi who was committed to making the problem in the Mediterranean a focus of foreign policy and migration became an important political agenda.
\end{abstract}

Keywords: International Migration, Morroccans, Operation Mare Nostrum, Italian

\section{Introduction}

Italy is the destination for migration and Libya is the main gateway for sending migrants by sea. Political instability in Libya due to the Arab Spring became fertile ground for smugglers to send thousands of irregular migrants from mainland Africa across the Mediterranean to Europe (Toaldo, 2015). The number of irregular migrants who come to cause problems for Italy. Italy is a country that is quite focused on resolving irregular migrant problems, but 
regulations regarding migrants are still said to be unsuccessful given the growing number of migrants. Migrants who arrive are often referred to as "Marocchini" or Moroccans. "Marocchini" is only used as a term for migrants originating from Africa because in reality the number of migrants from Morocco is only around $10 \%$ of the total migrants recorded by the Italian side (Knepper, 2007). Over time and with the crisis in the Middle East and North Africa, there was an irregular flow of migration into Italy.

Migrants who will go to Italy by sea are at a very minimal level of security. This is due to poor accommodation. Therefore the safety level of migrants at sea cannot be guaranteed and conditions can turn fatal at any time. The lack of safety due to smugglers do not guarantee security at all even though they have to pay handsomely namely between 1000 to 2000 dinars and even 3000 dinars (Fargues \& Bonfanti, 2014). On October 3, 2013, 518 to 548 Eritrean migrants, sailing from Libya to Italy, had an accident. The ship carrying the migrant sank in the waters of Lampedusa. 360 fatalities (Italian Navy, 2015). On 11 October 2013, a similar event occurred again, migrant ships sank near the waters of Lampedusa and Malta. This tragedy was included in a humanitarian tragedy which resulted in hundreds of deaths. One week after the incident, an operation was formed called Operation Mare Nostrum.

Operation Mare Nostrum has the main objective of saving migrants in the Sea. The noble aim of the search and rescue operation in the Mediterranean has actually come under fire from the British, the Foreign and Commonwealth Minister, Lady Anelay said that it would not support search and rescue operations in the Mediterranean, it was felt would only make a pull factor for migrants (The Guardian, 2014) and the operation could encourage more people to try to cross dangerous seas to enter Europe (BBC, 2014). In carrying out Operation Mare Nostrum the Italian must spend a significant amount, which is 9 million Euros per month (Amnesty International, 2014). This high cost is borne by the Italian government itself, due to weak support from countries in the European Union. Italy is not only a destination country, but also a transit country for migrants (Marconi, 2016). The making of Italy as a transit country resulted in widespread irregular migration to other countries in the European Union especially Germany which is also the main destination for migrants to live in (Reuters, 2016). The formulation of the problem that arises from this study is "Why does Italy remain consistent in helping migrants in Mediterranean waters through Operation Mare Nostrum? and is Operation Mare Nostrum effective in reducing migrant mortality and irregular migration rates? "

This research uses the concept of norms in constructivism. Norms have standards of behavior that contain prohibitions and recommendations of action. In this concept, relations between countries are likened to social relations that occur in society. Or in other words the position of the state in the international world is the same as the position of individuals in society (Rosyidin, 2104: 47). The state takes an action or makes a policy not because of the interests of the country alone. In this case, norms become a reference for countries to act on international issues. Norms are closely related to appropriate behavior to do (Rosyidin, 2014). Norms represent shared expectations about behavior derived from beliefs, standards of behavior, international conventions and decision-making procedures (Beasly, 2013).

The state acts based on what is appropriate and good to do. This concept is called the logic of appropriateness. The logic of appropriateness means that the state does not see whether 
norms serve its interests or not, but they see norms as something that gives meaning to actions that are considered good or appropriate (Rosyidin, 2014).

\section{Discussion}

Italy as a destination country for migration formed a rescue operation on 15 October 2015 which was named Operation Mare Nostrum (Italian Ministry of Defense, 2016). Operation Mare Nostrum began on 18 October 2011 one week after the shipwreck near the waters of Lampedusa (Italian Navy, 2016). Mare Nostrum's operations are classified as Search and Rescue (SAR) operations.

Mare Nostrum's operations take place in international waters, using Navy-owned equipment and ships with the aim of identifying migrants and smuggler-owned vessels as early as possible (Amnesty International, 2014: 23). Ships aboard smugglers, commonly called mothership, are larger vessels and are usually fishing vessels. The ship is the starting place for sending migrants before moving to the next ship to reach Italy (Italian Ministry of Defense, 2014). Operation Mare Nostrum operates in a range of $43,000 \mathrm{~km} 2$, then extends to 400 miles around the waters of Lampedusa with 150 miles to the east, expanding the area of operation makes the overlapping SAR region owned by Malta and Libya (Amnesty International, 2014: 26).

Operation Mare Nostrum cooperates well with Italian coast guards. The coast guards through the Rescue Coordination Center (RCC) in Rome are responsible for coordination with SAR operations in the SAR zone zone. The Rome RCC accepts all requests for assistance via telephone lines and is then present to carry out missions in accordance with the United Nations Convention on the Law of the Sea (UNCLOS), the International Convention on the Safety of Passenger at Sea (SOLAS) and the International Convention on Search and Rescue at Sea (SAR)) which is indeed the basis of international maritime law in the event of a humanitarian event at sea (Beckwith, 2014).

At first, Italy also cooperated with Libyan coast guards, but the collaboration foundered along with Libyan conditions which could not control sea surveillance. Though this cooperation is considered to be very effective if Libya as a transit country can optimize coastal guarding. So that most control of the Mediterranean sea is carried out by the Italians.

Vessels belonging to the Italian Navy can detect the presence of fishing boats boarded by migrants including asylum seekers in the middle of the sea. That way, to reduce the risk of a humanitarian disaster, members of the rescue team take early action by moving migrants from fishing boats to ships owned by the Navy for evacuation and data collection at the same time (Ramazzotti, 2016). Evacuation and data collection is carried out by members of the Navy by identifying their name, age, nationality and taking pictures. In addition, a medical team was also deployed to monitor the health conditions of migrants (Amnesty International, 2014: 25).

Operation Mare Nostrum ended one year after it was formed, precisely on October 31, 2014. In response to the misery of migrants at sea, Operation Mare Nostrum has conducted 421 operations at sea and saved 150,810 migrants (Italian Navy, 2016). The success of the rescue was due to the support of sophisticated equipment and a large cost because Italy had to spend 9,000,000 Euros per month to fund the operation (Amnesty International, 2014: 22). 


\section{Macrothink}

The ship's obligation to save life at sea is more specifically explained in UNCLOS 1982 article 98 (1) which contains each country requiring the captain of a ship sailing under its flag to, as long as it can do so without causing great harm to the ship, crew or passengers : (a) provide assistance to anyone found at risk of loss of life at sea; (b) go immediately to help people who are in trouble, this is done if they obtain information about the rescue needs of victims, as long as these actions can and may be carried out by the ship receiving the information. In addition, based on CHAPTER V article 33 paragraph 1 of the International Convention for the Safety of Life at Sea (SOLAS) in 1974 it was stated that the captain of the ship who was in a position to be able to provide assistance from the signal receiver originated from people in trouble at sea, bound or obliged to provide assistance quickly, such assistance can be done if the ship can obtain complete information or see the condition of the ship's service to do so. The obligation to save must be carried out regardless of the nationality, status of the person or the conditions in which they were found.

In the International Convention on Maritime Search and Rescue or the SAR SAR convention stated that the rescue mission is aimed at anyone who experiences a tragedy at sea regardless of nationality and status and condition when found and provides medical or other needs that are felt necessary, and deliver victims to safer place. In May 2004, the Maritime Safety Committee of the International Maritime Organization (IMO) adopted the Amendments to the SOLAS and SAR Conventions, this was done to strengthen the SAR system. The amendment applies to countries that ratified it on July 1, 2006 (Amnesty International, 2014).

The guideline used as a reference in the rescue mission is the resolution of the Maritime Safety Committee (MSC) 167 (78) in 2004, namely: (1) The government of a country is responsible for the SAR area where the victim was found and provides and ensures a safe place; (2) a safe place is a location where rescue operations can end, and where the safety or lives of victims are no longer threatened, basic human needs (such as food, shelter and medical needs) can be met and transportation arrangements can be made for victims; (3) Relief vessels can be used as safe temporary rescue sites, and must be released from their responsibilities as soon as alternative arrangements can be made; (4) Avoiding the reduction of victims saved at sea in places where their lives can be threatened; (5) The identification of rescued victims may not take sides or see the conditions and status attached to migrants, such as citizenship status.

The normative aspects mentioned in the 2004 maritime safety committee (MSC) resolution were implemented by Italy through Operation Mare Nostrum, the first in the case of rescuing migrants who crossed the Mediterranean Sea from Libya on January 24, 2014. Before migrants traveled, they paid money to smugglers. as much as 600 Euros per person. They were promised to land in Italy in 15 to 20 hours, but in reality, the journey taken was three days. Migrant who traveled at that time numbered 225 people from Africa, specifically Gambia and Nigeria. On the way the ship experienced engine problems. Not long after that, aid came in the form of the arrival of Italian military helicopters and warships. The Italian military through Operation Mare Nostrum immediately identified migrants. Furthermore, the migrants are given adequate housing, food and drink to meet their needs. Upon arrival at the port of Augusta, Italy the migrants were re-identified and taken to Palermo and received a three-month stay (Borderline-Europe, 2014). 


\section{Macrothink}

The second case, migrants from Gambia who were rescued by Operation Mare Nostrum. Migrants who will cross the Mediterranean Sea to Italy will be charged 1,000 Libyan Dinars or 600 Euros in March 2014. They use wooden ships to sail, on the second day the ship they are traveling in has experienced engine problems and food supplies have run out. The condition is worsened when the communication device in the ship falls into the sea. In the end, the ship's captain used a compass as a means to get to Italy. Not long after that a helicopter and Italian military ship arrived to save them. Inside the ship, officers identify with fingerprints in accordance with the rescue regulations. They found temporary accommodation on an Italian military ship for four days until they finally landed at the port of Augusta (Borderline-Europe, 2014).

The third case, the arrival of 887 migrants from Syria and Sub-Saharan countries in Africa on May 7, 2014. They are all migrants rescued by the Italian Navy in Operation Mare Nostrum. The migrants were rescued by Italian Navy ships and rescue vessels in the form of cargo ships. The condition of the cargo ships that helped the migrants turned out to be a problem because the ship was only able to accommodate 10 crew members, but they accommodated 343 migrants. Knowing this, the Italian military did not remain silent, they prepared ships to accommodate migrants from cargo ships that had carried out rescue, so that migrants get a more appropriate place (Borderline-Europe, 2014).

The fourth case, on 10 June 2014, 102 migrants sailed from Libya via the Mediterranean to Italy. After five days of sailing, they ran out of water and were adrift in the sea. Two days later, the migrant was rescued by an Italian warship. The ships passed as many as seven units and immediately rescued. They get temporary shelter on an Italian warship for three days with adequate facilities. While on the ship, the migrants were treated very well by the Italian military until they finally landed in the port of Augusta and were immediately identified by Italian authorities. As many as 25 migrants were rushed to the nearest hospital to get treatment due to illness (Borderline-Europe, 2014).

The case that has been explained is an effort to implement the normative aspects contained in the resolution of the Maritime Safety Committee. The first normative aspect of the government's responsibility to rescue migrants who are experiencing difficulties at sea is shown by Italy's actions to send a Navy fleet to help migrants affected by disaster. The second normative aspect concerns the provision of safer temporary shelter and facilities such as food and beverages. This was demonstrated by Italy by preparing temporary shelter for migrants both on ships and on land, although not yet at maximum level, Italy has made optimal efforts such as by continuing to make the house a place of rest.

The third aspect of rescue vessels (non-military) being a safe temporary shelter and must be released as soon as possible by moving migrants to military ships, try to be shown by Italy in the third case in May 2014. In addition to being helped by Italian military ships, migrants also rescued by a freighter receiving a rescue signal As a result of an inadequate place on a cargo ship and the availability of an Italian military ship the cargo ship was immediately dismissed and migrants were transferred to an Italian Navy ship.

The fourth normative aspect regarding victims that should not be brought down in dangerous places, try to show Italy in its actions by lowering migrants in the port of Augusta, Sicily to immediately get help. The fifth normative aspect regarding impartial identification of the 
conditions and status of migrants, try to show the Italian government by rescuing all migrants affected by disasters at sea, in addition to that migrants also get good treatment from Italian Navy soldiers on duty as shown in the fourth case in 10 June 2014.

Mare Nostrum's operations ended on 31 October 2014 (Italian Navy, 2016). within one year of the operation is able to capture smugglers in Libya, as many as 330 smugglers. With the arrest of smugglers, it turns out that it has not been able to reduce the number of irregular migrants to Italy, as the graph below shows:

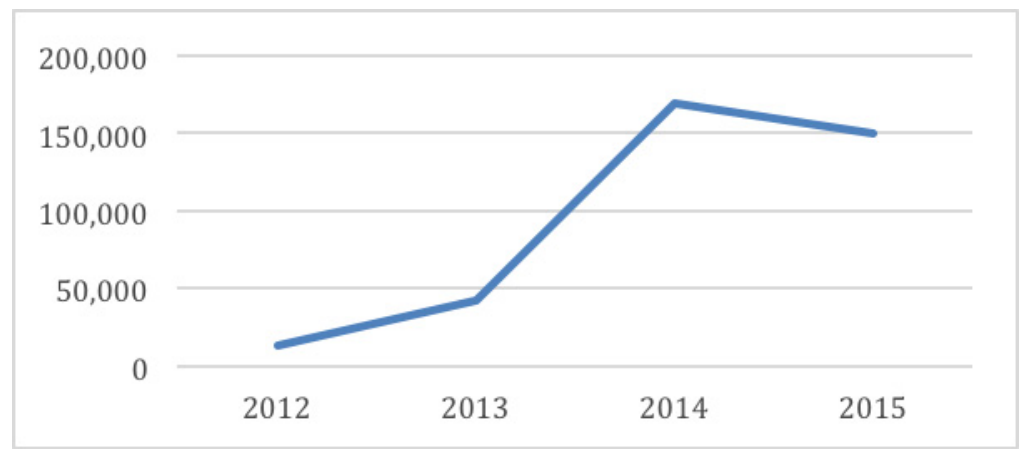

Figure 1. Number of Regular Migrants in Italy in 2012-2015

Source: Italian Ministry of Home Affairs 2015 \& IMO 2016

From the graph above it can be concluded that in 2012 there were irregular migrants entering the Italian region in the amount of 13,267 people and continued to increase from 2013 to 2014, a drastic surge was shown in 2014 of 170,100 from 42,925 in 2013. In 2015 after the cessation of Operation Mare Nostrum the number of migrants remained in a high position at 150,317 people. The figure of 150,317 is a very high number compared to 2012 and 2013, but the figure is not too far from 2014, which reached 170,100. The significant increase in the entry of irregular migrants in Italy is contrary to one of the objectives of Operation Mare Nostrum previously described, namely to reduce the rate of irregular migration. This drastic increase in the arrival of irregular migrants in 2014 led other governments to assess the rescue operation of Mare Nostrum as a reason for the high rate of migration into Italy and Europe. But is it true that Operation Mare Nostrum is a cause of high irregular migration flows, in fact Operation Nostrum Mare does not affect migrants' desire to carry out migration (Patalano, 2015).

Migrants will continue to migrate because they want to get a better life, this is also related to the desire to get a safer place to live (Llewellyn, 2015). A recognition of migrants from the Gambia, he stated that the situation in Libya was getting worse, they could have been looking for work in Libya but it was very risky, so there was no other choice but to save themselves, the cost of travel to Italy via smugglers was much cheaper, which is around 1000 dinars if compared to the cost of returning to their home country of 2500 dinars and only people who have money can return to their home country (Amnesty International, 2014). In other words, migrants and refugees choose the risk of sailing using smugglers' boats far from safe to reach Italy (Bonfanti and Fargues, 2014). 
Safety risks in the Mediterranean Sea are the choice of migrants themselves. Data released by the Italian Ministry of the Interior shows that the number of migrant arrivals in 2015 decreased despite not being significant after the termination of Operation Mare Nostrum, which is still at 150,317. Likewise, with the death rate and loss of irregular migrants in the Mediterranean Sea, shown in the graph below:

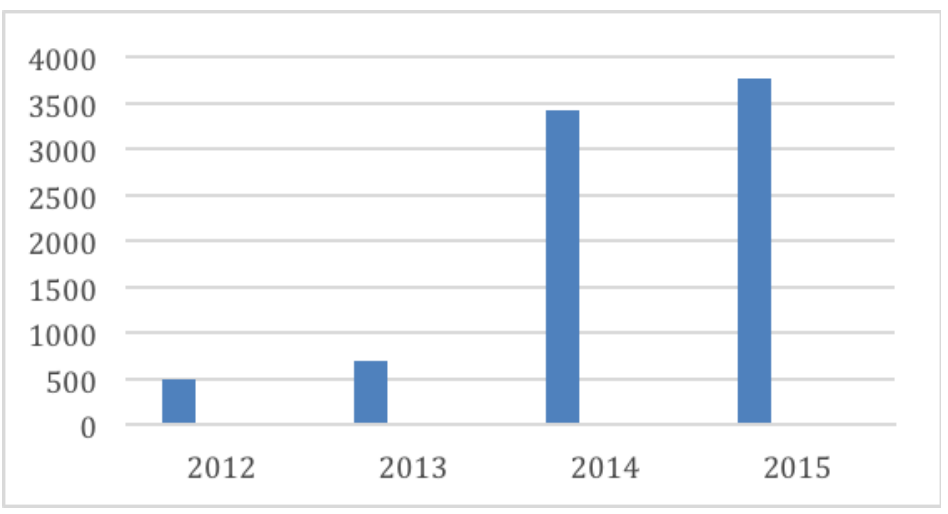

Figure 2. Number of Death and Loss of Regular Migrants in the Mediterranean Sea in 2012-2015

Source: UNHCR, 2016

Mortality and loss of migrants in Mediterranean waters continued to increase from 2012 to 2015. 2012 was the year in which Operation Mare Nostrum had not yet been established. And in that year there were already data records regarding the death and loss of irregular migrants, as many as 500 people. The following year, 700 people were declared dead and missing in the Mediterranean Sea. From 18 October 2013 to 31 October 2015 Operation Mare Nostrum was officially formed, the operation saved more than 100,000 lives but still could not stem the death and loss of migrants at sea that year. So that in 2014 3,419 migrants were declared dead and missing. In 2015 the condition of maritime security in the Mediterranean region did not improve, the death rate actually increased although not significantly as many as 3,771 people. This reinforces the answer that Operation Mare Nostrum can be said to be ineffective because the death rate of migrants at sea actually experienced a rapid increase in the current year of operation.

On August 19, 2014, before deciding to stop Operation Mare Nostrum, Italian Minister of the Interior, Angelino Alfano invited European Union countries to join the handling of the migrant crisis in Italy but these efforts had not been successful. On August 27, 2014, this Italian request began to be heard by the European Union, which in turn planned to form an operation to secure EU territory through Frontex, an organization specifically protecting the European border (Llewellyn, 2015).

The Mare Nostrum operation was stopped on the grounds that this operation was a temporary operation (Italian Ministry of the Interior, 2015) and a huge Italian expenditure that had to be borne by its own country (Llewellyn, 2015: 16). The increase in irregular migration and the death rate of migrants in the Mediterranean Sea creates a dilemma in the Italian camp, but at least Italy has tried to take action that should be in accordance with the logic of 
appropriateness. The Italians themselves do not regret the existence of these operations despite pouring huge amounts of funds into helping and upholding human rights at sea, so that material losses are not a matter of regret. As a form of adherence to the norm, after the termination of Operation Mare Nostrum, Italy continued to show its consistency with the regulations on sea rescue, as evidenced by the formation of a transitional operation called Device Naval Surveillance and Maritime Safety (DNSSM) which operates in the Mediterranean Sea from the 1st November to 31 December 2014 (Italian Navy, 2016). Italy also continues to make rescue in the Mediterranean region after Operation Mare Nostrum (CNN, 2015), although smaller, this is a sign that Italy is consistent in obeying norms.

\section{Conclusion}

Migration rates in Italy are dominated by irregular migrants by Citizens of Eritrea, Somalia, Mali, Gambia, Nigeria and then Syrian dominance. The complexity of migration flows in Italy is caused by migrants' economic motives, refugees and asylum seekers blending into one, this does not hamper Operation Mare Nostrum and continue to carry out rescue missions regardless of migrant status in accordance with applicable sea law.

The aim of the glorious operation of Mare Nostrum, instead, was assumed that this operation was an attractive factor for irregular migration to Italy and spread to Europe, giving rise to a paradox. In fact, irregular migration rates in Italy experienced a rapid increase when the implementation of the Mare Nostrum Operation, which is 170,100 from 42,925. This operation cannot stem the desire of migrants to migrate. And migrant mortality rates also increased rapidly in 2014 to 3,419 people from 700 in 2013. Thus, Italy experienced a dilemma in carrying out this humanitarian mission, and in the end the operation was stopped one year after it was formed. As a result of increasing irregular migration rates and deaths at sea, Operation Mare Nostrum can be said to be ineffective because it has not been able to reach its initial goal to reduce irregular migration rates and reduce mortality in the Mediterranean.

After the cessation of Operation Mare Nostrum, Italy continued to show consistency in complying with the laws of the sea and human rights, by continuing to carry out surveillance and rescue at sea. This was reinforced by the statement of the Italian Prime Minister, Matteo Renzi who was committed to making the problem in the Mediterranean a focus of foreign policy and migration became an important political agenda.

\section{Reference}

Amnesti Internasional. (2014). Lives Adrift: Refugees and Migrants in Peril in the Central Mediterranean. amnesty.org.

Beasly, R., \& Juliet, K. D. (2013). Foreign Policy in Comparative Perspective: Domestic and International Influence on State Behavior. London: SAGE Publications.

Bianchi, Mi., Paolo, B., \& Paolo, P. (2010). Do Immigrant Cause Crime? Journal of the European Economic Association.

Borderline-europe. (2014). Rescue at Sea: The Situation in Sicilian Strait.

Castles, S., \& dan M. J. Miller. (2003). Conclusion: Migration in the Post-Cold War Era, 
dalam the Age of Migration: International Population Movements in the Modern World. New York: Palgrave Macmillan.

CNN. (2015). How Italy's Fascist Past Echoes in Migrant Crisis. Dalam http://cnn.com. Diakses pada 29 Desember 2015 pukul 21.00.

Cogolati, S. (2015). Migrants in the Mediterranean: Protecting Human Rights. Policy Department, Directorate-General for External Policies, 14.

ECRE. Mare Nostrum to End - New Frontex Operation Will Not Ensure Rescue of Migrants in International Waters. 2014. Dalam http://ecre.org. Diakses pada tanggal 8 Juni 2016 pukul 20.00 .

Fargues, P., \& dan Sara B. (2014). When the best option is a leky boat: why migrants risk their lives crossing the Mediterranean and what Europe is doing about it. Migration Policy Centre.

Hammond, T. (2015). The Mediterranean Migration Crisis. Foreign Policy Journal, 1.

IOM. (2006). Hak - Hak Pekerja Migran. Jakarta: IOM.

Kementerian dalam Negeri Italia (Ministero dell Interno). (2014). Migration Phenomenon (Fenomeno Migratorio). Dipartimento della Pubblica Sicurezza.

Kementerian P. I. (Marina Difesa). (2014). Retrieved from "Il Ministro della Difesa Mario Mauro incontra il Primo Ministro Sloveno - la Slovenia partecipa all'emergenza immigrazione con una nave in Mare Nostrum: http://www.marina.difesa.it

Llewellyn, S. (2015). Search and Rescue in Central Mediterranean Sea. Mission Echanges wet Partenarias-Migreurop-Watch the Med-Arci.

Marconi, G. (2016). Transit cities in transit countries: Steering the consequences of US and EU closed door policies. Universita Luav di Venezia.

Mare Nostrum Operation. Dalam http://www.marina.difesa.it. Diakses pada tanggal 7 Agustus 2016.

Migration Policy Centre (MPC). (2013). Libya: The Demographic -Economic Framework of Migration, the Legal Framework of Migration, The Socio- Political Framework of Migration. European University Institute and Robert Schuman Centre for Advanced Studies.

Panebianco, S. (2016). The Mare Nostrum Operation and the SAR Approach: the Italian respone to address the Mediterranean migration crisis. Catania: Jean Monnet Centre, University of Catania.

Paoletti, E. (2012). Migration Agreements between Italy and North Africa: Domestic Imperatives versus International Norms. Middle East Institute, dapat diakses melalui http://www.mei.edu

Patalano, A. (2015). Nightmare Nostrum? Not Quiet. The RUSI Journal, 160(3), 14-19.

Ramazzotti, S. (2016). Lampedusa: Mare Nostrum. Milan: Parallelozero. 


\section{Macrothink \\ International Journal of Global Sustainability \\ ISSN 1937-7924 2019, Vol. 3, No. 1}

Rosyidin, M. (2015). The Power of Ideas: Konstruktivis dalam Studi Hubungan Internasional. Yogyakarta: Tiara Wacana.

The Globe Daily Mail. Migrants' deaths stoke anti-immigrant rhetoric in Italy. 2013. Dalam http://www.theglobeandmail.com. Diakses pada tanggal 24 Juni 2016 pukul 19.00.

The Guardian. (2014). UK axes support for Mediterranean migrant rescue operation. Dalam https:/www.theguardian.com/politics/2014/oct/27/uk-mediterranean-migrant-rescue-plan.

Diakses pada 23 September 2016 pukul 14.00

Toaldo, M. (2015). Migration Through and From Libya: A Mediterranean Challenge. Istituto Affari Internazional working papers.

Torresi, T. (2013). An Emerging Regulatory Framework for Migration: The Libya-Italy Agreement and The Right of Exit. Griffith Law Review, 22(3).

UNHCR subregional operations profile - Northern, Western, Central and Southern Europe. (2015). Dalam http://www.unhcr.org. Diakses pada tanggal 8 Juni 2016.

UNHCR. (2016). Central Mediterranean Sea Initiative (CMSI). Dapat diakses melalui www.unhcr.com

Wendt, A. (1992). Anarchy is What States Make of It. International Organization, 46(2).

\section{Copyright Disclaimer}

Copyright for this article is retained by the author(s), with first publication rights granted to the journal.

This is an open-access article distributed under the terms and conditions of the Creative Commons Attribution license (http://creativecommons.org/licenses/by/3.0/). 